\title{
Analysis of solar thermal systems and future development possibilities in Lithuania
}

\author{
Rokas Valančius ${ }^{1}$, \\ Andrius Jurelionis ${ }^{1}$, \\ Juozas Vaičiūnas ${ }^{1}$, \\ Eugenijus Perednis ${ }^{2}$, \\ Vykintas Šuksteris ${ }^{3}$ \\ ${ }^{1}$ Faculty of Civil Engineering \\ and Architecture, \\ Kaunas University of Technology, \\ Studentų str. 48, \\ LT-51367 Kaunas, Lithuania \\ E-mail: rokas.valancius@ktu.lt; \\ andrius.jurelionis@ktu.lt; \\ juozas.vaiciunas@ktu.lt \\ ${ }^{2}$ Laboratory for Renewable Energy \\ and Energy Efficiency, \\ Lithuanian Energy Institute, \\ Breslaujos str. 3, \\ LT-44403 Kaunas, Lithuania \\ E-mail Eugenijus.Perednis@lei.lt \\ ${ }^{3}$ JSC "Terma Consult", \\ Europos pr. 110, \\ LT-46351 Kaunas, Lithuania \\ E-mailinfo@termaconsult.lt
}

\begin{abstract}
Solar thermal systems with a total solar panel area varying from 2 to $204 \mathrm{~m}^{2}$ have been installed in Lithuania for over 20 years. The reviewed solar thermal domestic hot water systems in Lithuania produce up to $528 \mathrm{kWh}$ per year per one square meter of solar collector absorber area. However, the performance of these systems varies depending on the type of energy users, equipment and design of the systems, as well as their maintenance. The aim of this paper was to analyse solar thermal systems from the perspective of energy production and economic benefit as well as to outline the differences of their actual performance compared to the numerical simulation results. A number of different solar thermal systems in Lithuania were selected for the analysis varying both in equipment used (flat type solar collectors, evacuated tube collectors) and type of energy user (domestic hot water heating, swimming pool, district heating). The simulation software Polysun 8.1 was used for evaluation of solar thermal system performance, as well as financial analysis of alternatives of these systems. The results of the analysis showed that in the analysed cases the gap between measured and modelled data of heat energy produced by solar thermal systems was up to approximately $11 \%$. The calculation of internal rate of return showed that a grant is required in most cases for solar thermal projects to be fully profitable.
\end{abstract}

Key words: solar collectors, solar thermal systems, domestic hot water, energy prices, simulation and monitoring, payback time

\section{INTRODUCTION}

Renewable energy consumption continued to grow in recent years alongside with the increasing global energy consumption, particularly in developing countries, and a dramatic decline in oil prices during the second half of 2014. Renewable energy provided an estimat- ed $19.1 \%$ of global final energy consumption in 2013, and growth in capacity and generation continued to expand in 2014.

The deployment of solar thermal technologies continued to slow, mostly due to declining markets in Europe and China. The cumulative capacity of water collectors reached an estimated 406 GWth by the end of 2014 (with air 
collectors adding another 2 GWth), providing approximately $341 \mathrm{TWh}$ of heat annually. China accounted for approx. $80 \%$ of the world market for solar water collectors, followed by Turkey, Brazil, India and Germany. The trend continued towards larger domestic hot water (DHW) systems in hotels, schools and other large complexes. The interest in the use of advanced collectors for district heating systems, such as solar cooling and industrial applications was growing as well, although advanced systems represent only a small fraction of the global market [1].

In 2014, the European market underwent a reduction in the newly installed capacity. In 2014, the market amounted to 2 GWth (approximately 2.9 million $\mathrm{m}^{2}$ ). This represents a decrease of $7.1 \%$ in comparison with the previous year. The total installed capacity registered a net increase of $1.6 \mathrm{GWth}$, now reaching 31.8 GWth (45.4 million $\mathrm{m}^{2}$ ). This represents an increase of 5.3\% compared with the total installed capacity at the end of 2013. Only about $10400 \mathrm{~m}^{2}$ (7280 kWth) of glazed solar collectors were installed by the end of 2014 in Lithuania, and the applications were mostly limited to single-family buildings [2].

The major part of thermal energy used in public and multi-family buildings in Lithuania is supplied via the district heating network. $72.4 \%$ from all district heating produced energy was used for household purposes in 2012 [3], and the price in different Lithuanian cities varied in the range from 0.047 to $0.091 \mathrm{Eur} / \mathrm{kWh}$. In the last year, district heating energy price dropped by $9.3 \%$ [4]. Quite frequently, natural gas, biofuel or electricity is used for building heating systems.

Despite the growth of energy prices during the past decade, switching from natural gas to biofuel reduced the district heating energy price significantly within last two years. However, due to a dramatic decline in oil prices during the second half of 2014, conventional fuel prices decreased as well [5]. Energy prices for electricity, natural gas and district heating are presented in Fig. 1.

The aim of this study was to review the existing solar thermal (ST) systems and their potential in Lithuania in relation to traditional energy prices and government policies.

\section{REVIEW OF SOLAR THERMAL MARKET IN LITHUANIA}

The average global solar irradiation in Lithuania is similar to the irradiation levels in such countries as Germany, Austria, Denmark, Poland, Latvia and Estonia with the annual potential of solar energy yield of approx. $1000 \mathrm{kWh} / \mathrm{m}^{2}$. The daily potential in the country varies from $0.55 \mathrm{kWh}$ in January to $5.8 \mathrm{kWh}$ from one square meter in June; therefore, almost the whole irradiated solar energy can be collected during the warm period of the year (from April till the end of October). Due to this fact, solar hot water (SHW) systems are most efficient in DHW applications in Lithuania [6]. Nevertheless, technical-economic potential of solar heat energy production in the country reaches up to $1.5 \mathrm{TWh} /$ year (129 ktoe).

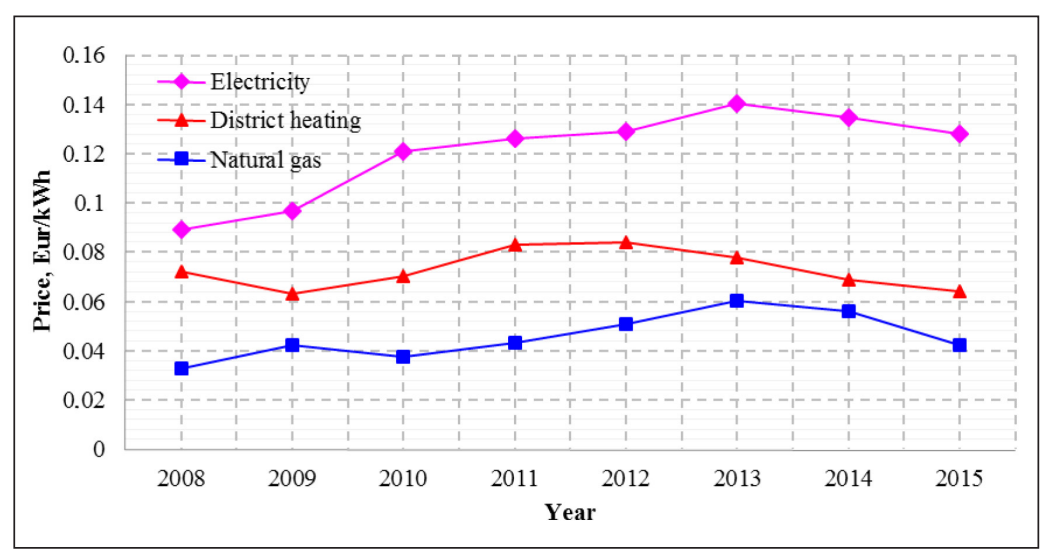

Fig. 1. Dynamics of energy prices in Lithuania from 2008 to 2015 
The values of expected solar energy yield are increasing during the last decade as solar irradiation increased by $7 \%$ during the years of 2005 to 2014 compared to the long-term statistical data [7].

Several studies showed that despite the fact that evacuated tube and flat plate collectors are considered suitable for solar heating in Central European Climates, the evacuated tube collectors do not reach the additional expected energy yield [8]. Flat plate collectors and evacuated tube collectors produce the same amount of energy from effective area during summer season in Lithuania, but it is much less expensive to use flat collectors in most cases [9-11]. In recent years, the price of evacuated tube collectors is slowly decreasing, and the usage of this technology is increasing, but there is still a lack of real efficiency and life span data at the moment. According to the European standard [12] the life span of solar collectors is from 15 to 25 years, but the life of the vacuum varies from collector to collector, somewhere from 5 to 15 years [13].

Some studies in Lithuania and in other countries of similar climate showed that small- and medium-scale solar DHW systems with flat plate or evacuated tube collectors can produce from 335 to $523 \mathrm{kWh} / \mathrm{m}^{2}$ of thermal energy per year, and the payback time of these systems is over eight years without subsidies. The potential of ST systems is quite high; however, the support from government and EU funds is still necessary in most cases to achieve reasonable payback [7, 14-19]. In Lithuania, some limited subsidy systems and funds for renewable energy installations exist since 2005. Depending on a project, it is possible to apply for a subsidy covering from 30 to $100 \%$ of initial costs.

Some studies showed that relation between installation costs and area of the flat plate solar collectors (including heat storage tanks and auxiliary equipment) can vary in the range from 600 to $150 \mathrm{Eur} / \mathrm{m}^{2}$ in SHW from $10 \mathrm{~m}^{2}$ to $10000 \mathrm{~m}^{2}$. The installation costs, annual maintenance and repair costs vary in a wide range depending on the type of solar collectors and other components, but in general, larger SHW installations are relatively cheaper to maintain than small-scale SWH systems [20, 21]. Additional costs for design of the systems in Lithua- nia add up to $8 \%$ from the installation costs. In some cases, installing SHW systems in existing buildings can cost up to $20 \%$ more than in new buildings [7].

The number of medium-scale SHW systems in Lithuania are still relatively low at the time and represent the potential direction for development of these systems. There are a number of medium-scale SHW systems installed in the country varying from 60 to $204 \mathrm{~m}^{2}$ of the total solar panel area. Most of these systems were installed within the past few years in public buildings, hospitals and industrial facilities. The oldest still operating SHW system of $77 \mathrm{~m}^{2}$ was installed in 2002 in a children sanatorium "Žibutè" (Kačerginè). However, it took ten years for the first SWH system to be installed in a multi-family building, as the first such system was launched only in 2012 [7, 19, 22, 23].

Some studies in Lithuania showed that public and multi-family buildings represent one of the major potential for SWH installation, as it is one of the best renewable energy alternatives for these buildings $[7,14,19,24]$. More uniform DHW usage during the day is common for public or multi-family buildings, compared to the single-family houses. It is related to variability of occupants and their hot water consumption habits, and this aspect brings out a higher solar energy share without adding additional volume to the accumulation tank. Moreover, DHW consumption throughout the day presents a possibility to keep lower temperatures in the collectors even during periods of high solar radiation. Public or multi-family buildings provide a possibility to connect several users to the same combined SHW system; therefore, the heat losses due to transformation and transportation of hot water will be incurred to a lesser extent during the system operation [25].

\section{METHODS OF ANALYSIS OF SOME SOLAR THERMAL SYSTEMS IN LITHUANIA}

Ten different ST systems in different Lithuanian cities were evaluated in this study. Most of these systems were designed for DHW applications. Flat plate and evacuated tube collectors and other equipment produced by different manufacturers were used. All of these systems 
are in operation for up to 5 years. Only some of the systems are equipped with heat meters or monitoring systems and only a few have been supported by schemes of subsidy, which led to reduced investments. Technical and economic characteristics of the analysed systems are presented in Table 1.

The measured performance of the existing ST systems was compared to the theoretical values obtained by means of the simulation software Polysun 8.1 (Velasolaris, 2015). This simulation tool allows dynamic calculation of the annual solar energy yield and designing ST systems to achieve economic efficiency. All technical parameters of the existing systems such as inclination angle, orientation, energy demands and characteristics of the installed equipment were used as boundary conditions for the simulations.

Financial analysis was performed for ten different ST systems. In this study, an assumption was made that the entire cost of the ST systems is covered during the installation and the systems were installed without any subsidies. The life span of the ST systems is considered to be 20 years. Parameters used for financial assessment of the ST systems are presented in Table 2.
Table 2. Parameters used for the simulations of ST systems

\begin{tabular}{ll}
\hline Life span of ST systems, years & 20 \\
\hline $\begin{array}{l}\text { Specific district heating energy price } \\
\text { (average), Eur/kWh }\end{array}$ & 0.041 \\
\hline $\begin{array}{l}\text { Specific energy from natural gas price } \\
\text { (average), Eur/kWh }\end{array}$ & 0.076 \\
\hline Specific electricity costs (standard), Eur/kWh & 0.129 \\
\hline Index for energy prices, \% per year & 3.0 \\
\hline Interest capital, \% & 2.5 \\
\hline Running costs, \% & 1.5 \\
\hline
\end{tabular}

\section{RESULTS OF THE ANALYSIS}

Analysis showed that relation between installation costs and area of the flat plate and evacuated tube solar collectors (including heat storage tanks and auxiliary equipment) varies in the range of $320-1079 \mathrm{Eur} / \mathrm{m}^{2}$ in ST systems from 25 to $166 \mathrm{~m}^{2}$ gross area. The average price of flat plate solar collector systems is $527 \mathrm{Eur} / \mathrm{m}^{2}$, but the investment for evacuated tube solar collector systems per $1 \mathrm{~m}^{2}$ gross area in a wide range is 320-1079 Eur/ $\mathrm{m}^{2}$, with the average price of $657 \mathrm{Eur} / \mathrm{m}^{2}$. Compared to the analysis made ten years ago [18], the prices of ST systems have not significantly changed.

Table 1. Technical and economic characteristics of the analysed ST systems

\begin{tabular}{|c|c|c|c|c|}
\hline \multicolumn{2}{|r|}{ Description of ST systems } & $\begin{array}{l}\text { Total gross / ab- } \\
\text { sorber area, } \mathbf{m}^{2}\end{array}$ & $\begin{array}{c}\text { Investment per } \\
1 \mathrm{~m}^{2} \text { gross area, Eur }\end{array}$ & $\begin{array}{l}\text { Annual energy } \\
\text { production per } 1 \mathrm{~m}^{2}\end{array}$ \\
\hline \multirow{5}{*}{$\begin{array}{l}\frac{1}{\pi} \\
\frac{\pi}{0} \\
心 \\
0 \\
\frac{0}{0} \\
\frac{\pi}{0} \\
\frac{0}{0} \\
\frac{\pi}{0} \\
\frac{\pi}{4}\end{array}$} & SHW, main energy source - natural gas & $25 / 23$ & 519 & $512(2015)$ \\
\hline & SHW, main energy source - district heating & $40 / 37$ & 516 & $382(2015)$ \\
\hline & SHW, main energy source - district heating & $72 / 67$ & 418 & $\mathrm{n} / \mathrm{a}$ \\
\hline & SHW, main energy source - electricity* & $114 / 106$ & 479 & $488(2013)$ \\
\hline & $\begin{array}{l}\text { Indoor swimming pool heating and SHW. } \\
\text { Main energy source - natural gas** }\end{array}$ & $166 / 155$ & 701 & $411(2013)$ \\
\hline \multirow{5}{*}{ 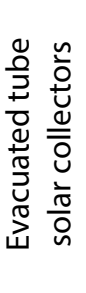 } & SHW, main energy source - electricity & $27 / 15$ & 571 & $528(2014)$ \\
\hline & SHW, main energy source - district heating & $36 / 33$ & 692 & $414(2015)$ \\
\hline & $\begin{array}{l}\text { Preheating the return water in the district } \\
\text { heating network }\end{array}$ & $82 / 72$ & 1079 & $343(2013)$ \\
\hline & SHW, main energy source - district heating* & $90 / 63$ & 621 & $\mathrm{n} / \mathrm{a}$ \\
\hline & SHW, main energy source - district heating & $145 / 77$ & 320 & $\mathrm{n} / \mathrm{a}$ \\
\hline
\end{tabular}

* Investment per $1 \mathrm{~m}^{2}$ gross area is estimated.

** System was not in operation for three weeks during August 2013.

*** System was upgraded a few times due to improper operation, and the total investment is estimated. 
The results of the analysis showed that ST systems with solar flat plate and evacuated tube collectors can produce from 343 to $528 \mathrm{kWh} / \mathrm{m}^{2}$, and almost the whole (approximately $80 \%$ ) irradiated solar energy can be collected during the warm period of the year (from March till October).

Simulations showed that the analysed ST systems in Lithuania can reduce greenhouse gas emissions from 49 to $232 \mathrm{~kg} \mathrm{CO} / \mathrm{m}^{2}$ absorber per year. However, $\mathrm{CO}_{2}$ reduction per absorber area can vary in a wide range depending on the type of the system and alternative source of energy production.

The price composition of the analysed ST systems is presented in Fig. 2. The price of solar collectors and mounting systems comprises more than half of the total system price in cases when evacuated tube collectors are used.

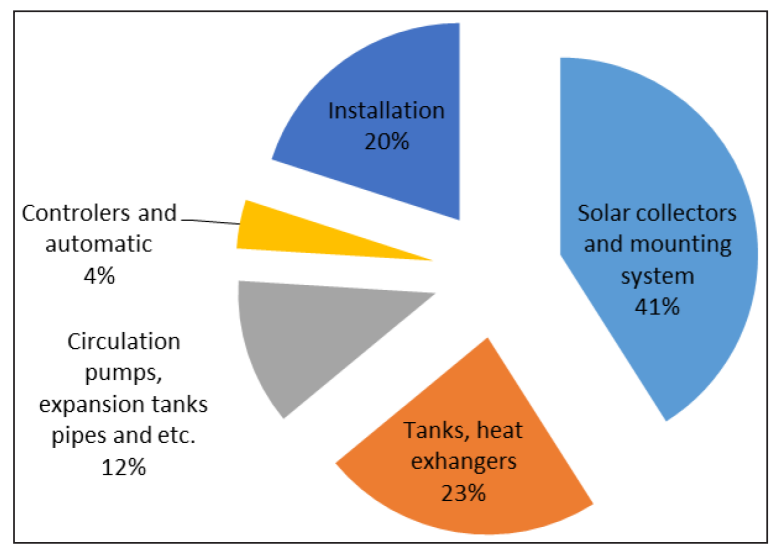

Fig. 2. Price composition of equipment in the analysed ST systems

The financial analysis showed that heat energy generated by the analysed ST systems is not competitive in most cases in comparison with district heating (payback period from 11 to 40 years) and natural gas applications (payback period from 24 to 27 years). But projects were fully profitable (payback period from 6 to 10 years) in cases when electrical energy was used as an alternative to energy produced by SHW systems. The average solar energy cost (life span 20 years) in the analysed cases was $0.073 \mathrm{Eur} / \mathrm{kWh}$.

\section{DISCUSSION AND CONCLUSIONS}

The results of the analysis presented in this study showed that ST systems with solar flat plate and evacuated tube collectors can produce from 343 to
$528 \mathrm{kWh} / \mathrm{m}^{2}$ of heat energy and reduce greenhouse gas emissions from 49 to $232 \mathrm{~kg} \mathrm{CO} / \mathrm{m}_{\text {absorber }}^{2}$ per year. The district heating system from a return pipe into a return pipe proved to be less effective compared to local SHW applications.

The results of the analysis showed that in the analysed cases the gap between measured and modelled data of heat energy produced by ST systems was approx. $11 \%$. From the economic perspective, the system with flat type solar collectors used for DHW production is profitable if compared with the electrical energy as an alternative.

The most expensive equipment in ST systems are solar thermal collectors. In the analysed cases, from $28 \%$ (flat plate collectors) to $51 \%$ (evacuated tube collectors) of initial investment is required to cover the costs of solar collectors themselves.

The market growth of ST systems in most countries depends on the policy of the governments. In Lithuania, the payback period of ST systems in most cases is too long to ensure the stable growth of ST applications without the governmental grants.

Received 16 March 2016 Accepted 22 April 2016

\section{References}

1. REN21. Renewables 2015 Global Status Report. Paris: REN21 Secretariat, 2015.

2. Solar Thermal Markets in Europe. Trends and Market Statistics 2014. ESTIF, June 2015.

3. Šilumos tiekimo bendroviu 2012 metu ūkinès veiklos apžvalga. LŠTA, 2012 (accessed 3 December 2015). http://www.lsta.lt/files/statistika/19493_ LSTA_Ukines\%20veiklos\%20apzvalga_2012_ WEB.pdf

4. Vidutine šilumos kaina gyventojams (po perskaičiavimu). LŠTA, 2015 (accessed 4 December 2015). http://lsta.lt/lt/pages/apie-silumos-uki/ silumos-kainos

5. Statistics Lithuania (accessed 17 December 2015). http://www.stat.gov.lt/en/home

6. Kytra S. Atsinaujinantys energijos šaltiniai. Kaunas: Technologija, 2006. 303 p.

7. Valančius R., Jurelionis A., Vaičiūnas J., Perednis E. Dimensioning of solar thermal systems for multi-family buildings in Lithuania: an optimisation 
study. Journal of Sustainable Architecture and Civil Engineering. 2015. Vol. 11(2). P. 32-40.

8. Trinkl C., Zörner W., Alt C., Stadler C. Performance of vacuum tube and flat plate collectors concerning domestic hot water preparation and room heating. Proceedings of 2nd European Solar Thermal Energy Conference, June 21-22, 2005, Freiburg, Germany.

9. Ambrulevičius R. Saulès kolektorių sistemų eksploatavimo ypatumai. LŽUUU ŽŨI instituto ir LŽŪ universiteto mokslo darbai. 2005. T. 37(4). P. 54-69.

10. Jonynas R., Valančius R., Šuksteris V., Perednis E., Mekas G. Study of medium scale solar water heating plants in Lithuania. Proceedings of ISES Solar World Congress 2011, 28 August - 2 September, 2011, Kassel, Germany. P. 921-927.

11. Šarka J., Streckienė G. Vienbučio pastato karšto vandens ruošimo plokščiaisiais ir vakuuminiais saulès kolektoriais ekonominis vertinimas. 17-osios Lietuvos jaunuju mokslininku konferencijos "Mokslas - Lietuvos ateitis" temine konferencija „Pastatu inžinerinès sistemos", $2014 \mathrm{~m}$. balandžio 11-12 d., Vilnius. P. 103-108.

12. EN 15459: 2006, Energy Efficiency for Buildings - Standard economic evaluation procedure for energy systems in buildings. P. 28.

13. Bhatia S. C. Advanced Renewable Energy Systems. CRC Press, 2014. P. 124.

14. Adomavičius V. Atsinaujinančiųjų energijos išteklių naudojimo galimybès daugiabučiuose namuose. Lietuvos taikomuju mokslu akademijos darbai: tarptautinis inovacinis taikomujų mokslo darbų žurnalas. 2010. Nr. 6. P. 107-122.

15. Ayompe L., Duffy A. Analysis of the thermal performance of a solar water heating system with flat plate collectors in a temperate climate. Applied Thermal Engineering. 2013. Vol. 58. P. 447-454.

16. Hugo A., Zmeureanu R. Residential solar-based seasonal thermal storage systems in cold climates: building envelope and thermal storage. Energies. 2012. Vol. 5(10). P. 3972-3985.
17. Jonynas R., Valančius R. The comparison of two different solar collectors systems. Proceedings of 8th EuroSun Conference of ISES Europe, 28 September - 1 October, 2010, Graz, Austria. P. 1-8.

18. Perednis E., Kavaliauskas A., Plikšienè V. Karšto vandens ruošimo naudojant saulès kolektorius efektyvumo tyrimai. Energetika. 2007. Nr. 1. P. 34-38.

19. Valančius R., Jurelionis A., Jonynas R., Katinas V., Perednis E. Analysis of medium-scale solar thermal systems and their potential in Lithuania. Energies. 2015. Vol. 8(6). P. 5725-5737.

20. Andrews D. et al. Background Report on EU-27 District Heating and Cooling Potentials, Barriers, Best Practice and Measures of Promotion, EC Joint Research Centre. Luxembourg: Publications Office of the European Union, 2012 (accessed 5 January 2015). https://setis.ec.europa.eu/system/ files/JRCDistrictheatingandcooling.pdf

21. Leutgöb K., Rammerstorfer J. Implementing the Cost-optimal Methodology in EU Countries. Case study Austria, BPIE, 2013.

22. Katinas V., Karbauskaite J., Perednis E., Valančius R. Efficiency analysis of combined biomass and solar energy in Lithuania. Clean Technologies and Environmental Policy. 2013. Vol. 15(4). P. 667-676.

23. Karbauskaitė J., Perednis E. Kačerginès vaikų sanatorijos šilumos energijos vartojimo mažinimo galimybès. Energetika. 2011. T. 57(1). P. 20-25.

24. Diliūnaite A. Atsinaujinančių energijos šaltinių panaudojimo daugiabučiuose gyvenamuosiuose namuose tyrimas. 16-osios Lietuvos jaunuju mokslininku konferencijos „Mokslas - Lietuvos ateitis" temine konferencija „Statyba“, $2013 \mathrm{~m}$. kovo 20-22 d., Vilnius. P. 1-7.

25. Žandeckis A., Timma L., Blumberga D., Rochas C. Possibilities for utilization of solar thermal energy in multi-family buildings in Latvia. Environmental and Climate Technologies. 2011. Vol. 6(1). P. 138-146. 
Rokas Valančius, Andrius Jurelionis, Juozas Vaičiūnas, Eugenijus Perednis, Vykintas Šuksteris

\section{SAULĖS KOLEKTORIŲ SISTEMŲ ANALIZE் IR ATEITIES PLĖTROS GALIMYBĖS LIETUVOJE}

\section{Santrauka}

Saulès kolektorių sistemos nuo 2 iki $204 \mathrm{~m}^{2}$ Lietuvoje instaliuojamos jau daugiau kaip 20 metų. Apžvalga parodè, kad saulès kolektorių sistemos, ruošdamos karštą vandeni, per metus gali pagaminti iki $528 \mathrm{kWh}$ energijos iš $1 \mathrm{~m}^{2}$ saulès kolektoriaus efektyvaus ploto. Be abejo, šių sistemų efektyvumas labai priklauso nuo sistemos tipo, projektuojant priimtų sprendimų, tinkamos sistemos eksploatacijos. Šio straipsnio tikslas - išanalizuoti skirtingas saulès kolektorių sistemas, ju pagaminamus energijos kiekius, galimą ekonominį efektą, taip pat palyginti matavimų metu gautus rezultatus su modeliavimų rezultatais. Keletas skirtingų saulès kolektorių sistemų, skirtų karštam vandeniui ruošti, baseinams šildyti bei integruotų ị centralizuotus šilumos tinklus, buvo pasirinktos analizei. Modeliavimo programa „Polysun 8.1“ buvo naudojama nustatyti saulès kolektorių sistemų efektyvumą, ìvertinti tokių sistemų ekonominę naudą. Analizès rezultatai parodè, kad skirtumai tarp modeliavimo metu gautu ir faktinių saulès kolektorių sistemų pagamintų energijos kiekių skyrèsi iki $11 \%$. Skaičiavimai atskleidè, kad dažniausiai saulès kolektorių sistemoms reikalingos dotacijos, kad jos būtų konkurencingos su tradiciniais energijos šaltiniais.

Raktažodžiai: saulès kolektoriai, saulès kolektorių sistemos, karštas vanduo, energijos kainos, modeliavimas ir analizè, atsipirkimo laikas 